\title{
Ketone bodies increase glomerular filtration rate in normal man and in patients with Type 1 (insulin-dependent) diabetes mellitus
}

\author{
R. Trevisan ${ }^{2}$, R. Nosadini ${ }^{1}$, P. Fioretto ${ }^{1}$, A. Avogaro ${ }^{2}$, E. Duner ${ }^{2}$, E. Jori ${ }^{1}$, A. Valerio ${ }^{1}$, A. Doria ${ }^{1}$ and G. Crepaldi ${ }^{1}$ \\ ${ }^{1}$ Patologia Medica I e ${ }^{2}$ Malattie del Ricambio, Policlinico Universitario, Padua, Italy
}

Summary. The purpose of this study was to investigate whether the administration of acetoacetic and hydrochloric acids in a group of control and Type 1 (insulin-dependent) diabetic patients influenced renal haemodynamics. Renal plasma flow increased from $657 \pm 88$ to $762 \pm 81 \mathrm{ml} \cdot \mathrm{min}^{-1}$. $1.73 \mathrm{~m}^{-2}$ in diabetic patients $(p<0.01)$ and from $590 \pm 71$ to $691 \pm 135$ in control subjects $(p<0.01)$. Glomerular filtration rate increased from $135 \pm 9$ to $180 \pm 8 \mathrm{ml} \cdot \mathrm{min}^{-1} \cdot 1.73 \mathrm{~m}^{-2}$ in diabetic patients $(p<0.001)$ and from $117 \pm 8$ to $145 \pm 7$ in control subjects $(p<0.01)$. Similar effects on renal haemodynamics, even if less pronounced, were observed with low dose acetoacetic but not with hydrochloric acid infusion. Total protein, $\beta 2$-microglobulin but not albumin excretion rates were increased by acetoacetic acid. We conclude that an acute increase in blood concentration of ketone bodies within the range found in diabetic patients with poor metabolic control (1) increases renal plasma flow and glomerular filtration rate both in control subjects and diabetic patients and (2) causes a tubular proteinuria.

Key words: Type 1 diabetes - glomerular filtration rate - ketone bodies - albumin excretion rate.
Type 1 (insulin-dependent) diabetic patients show an increase in glomerular filtration rate (GFR), in comparison with normal subjects, when insulin treatment is inadequate to achieve satisfactory metabolic control [1-5]. The elevated GFR found in diabetic patients in poor metabolic control can be rapidly reversed by intensive insulin treatment, whilst kidney size remains enlarged [6]. This discordance between structure and function could support the hypothesis that functional haemodynamic rather than morphological changes play a major role in the generation of diabetic nephropathy [7]. It has been postulated that high circulating concentrations of glucose [8], glucagon [9] and growth hormone [10] are responsible for the increase in GFR of poorly controlled diabetic patients. On the other hand, poorly controlled diabetes is characterized by abnormal blood concentrations of several hormones and metabolites. Concerning this issue, very little information is available on the individual role played by ketone bodies in determining haemodynamic changes in the kidney irrespective of changes of glucose, even if a high level of ketone bodies is one of the main clinical features of diabetic patients in poor metabolic control. Moreover, Christiansen et al. [8] pointed out that the acute changes seen in GFR following increments in plasma concentrations of glucose, glucagon and growth hormone within levels relevant to the clinical metabolic derangement shown by diabetic patients were $5 \%, 6 \%$ and $7 \%$, respectively, whereas GFR is increased by approximately $25 \%$ in diabetic patients in poor metabolic control. Thus, it can be postulated either that haemodynamic effects of these factors in the kidney are additive or that other hormonal and metabolic factors contribute to modulate GFR in vivo.

The current study was undertaken to investigate whether ketone bodies per se are capable of influencing renal function in normal subjects and Type 1 diabetic patients in strict metabolic control.

To avoid the interference of changes of other metabolic parameters, we used the insulin-glucose clamp technique [11] to keep constant circulating concentrations of glucose and insulin during acetoacetic acid administration.

\section{Subjects and methods}

\section{Subjects}

Fourteen Type 1 diabetic patients without proliferative retinopathy and clinical renal complications ( 7 male, 7 female), and 14 normal subjects ( 8 male, 6 female), were investigated after obtaining informed and written consent. Normal subjects were either medical staff of the department or subjects admitted in the ward who did not show any kidney, liver, heart and metabolic disease. The control sub- 
Table 1. Clinical features of Type 1 diabetic patients

\begin{tabular}{|c|c|c|c|c|c|c|c|c|c|c|c|c|}
\hline $\begin{array}{l}\text { Diabetic } \\
\text { patients }\end{array}$ & $\begin{array}{l}\text { Sex } \\
M / F\end{array}$ & $\begin{array}{l}\text { Body } \\
\text { surface } \\
\left(\mathrm{m}^{2}\right)\end{array}$ & $\begin{array}{l}\text { Body } \\
\text { mass } \\
\text { index }\end{array}$ & $\begin{array}{l}\text { Age } \\
\text { (years) }\end{array}$ & $\begin{array}{l}\text { Duration } \\
\text { of diabetes } \\
\text { (years) }\end{array}$ & $\begin{array}{l}\text { Insulin } \\
\text { require- } \\
\text { ment } \\
\text { (U/day) }\end{array}$ & $\begin{array}{l}\text { C-peptide } \\
\text { (ng/ml) }\end{array}$ & $\begin{array}{l}\mathrm{HbA}_{1 \mathrm{c}} \\
\%\end{array}$ & $\begin{array}{l}\text { Creatinine } \\
\text { clearance } \\
(\mathrm{ml} / \mathrm{min})\end{array}$ & $\begin{array}{l}\text { Blood } \\
\text { pressure } \\
(\mathrm{mmHg})\end{array}$ & $\begin{array}{l}\text { Albumin- } \\
\text { uria } \\
(\mathrm{mg} / 24 \mathrm{~h})\end{array}$ & $\begin{array}{l}\text { Other } \\
\text { pathologies }\end{array}$ \\
\hline 1 & M & 1.82 & 24.28 & 36 & 13 & 44 & 0.3 & 6.2 & 139 & $125 / 85$ & 9 & - \\
\hline 2 & $F$ & 1.71 & 19.72 & 42 & 21 & 58 & $"$ & 6.4 & 139 & $130 / 85$ & 8 & $\begin{array}{l}\text { Background } \\
\text { retinopathy }\end{array}$ \\
\hline 3 & $F$ & 1.69 & 19.16 & 47 & 16 & 51 & $"$ & 6.3 & 132 & $130 / 80$ & 12 & $\begin{array}{l}\text { Background } \\
\text { retinopathy }\end{array}$ \\
\hline 5 & $\mathrm{~F}$ & 1.66 & 22.03 & 21 & 2 & 32 & 0.8 & 6.8 & 111 & $115 / 75$ & 3 & _- \\
\hline 6 & $\mathbf{M}$ & 1.81 & 22.46 & 28 & 6 & 32 & 0.3 & 6.9 & 129 & $115 / 85$ & 7 & - \\
\hline 7 & $\mathbf{M}$ & 1.75 & 20.96 & 24 & 3 & 41 & $"$ & 6.6 & 117 & $125 / 70$ & 10 & - \\
\hline 8 & $\mathrm{~F}$ & 1.73 & 21.89 & 41 & 5 & 33 & $"$ & 7.2 & 132 & $120 / 60$ & 8 & - \\
\hline 9 & M & 1.94 & 23.15 & 16 & 4 & 27 & $"$ & 6.9 & 145 & $135 / 80$ & 11 & - \\
\hline 10 & M & 1.87 & 25.65 & 32 & 4 & 42 & $"$ & 7.0 & 148 & $120 / 85$ & 18 & - \\
\hline 14 & $F$ & 1.66 & 19.72 & 31 & 1 & 38 & $"$ & 6.9 & 119 & $140 / 75$ & 10 & - \\
\hline
\end{tabular}

${ }^{a} \mathrm{C}$-peptide plasma value following intravenous injection of $1 \mathrm{mg}$ of glucagon; ${ }^{\mathrm{b}}$ body surface area was estimated according to the formula of DuBois and DuBois (36)

jects' body mass index was $23.00 \pm 1.11 \mathrm{~kg} / \mathrm{m}^{2}$, body surface was $1.72 \pm 0.30 \mathrm{~m}^{2}$, and age was $28 \pm 4$ years. C-peptide levels were $3.6 \pm 0.4 \mathrm{ng} / \mathrm{ml}$ after intravenous injection of $1 \mathrm{mg}$ of glucagon, and blood pressure values were $120 \pm 6 \mathrm{mmHg}$ (systolic) and $80 \pm 4$ (diastolic). Haemoglobin $\mathrm{A}_{1 \mathrm{c}}$ levels were $4.8 \pm 1.9 \%$, creatinine clearance $127 \pm 11 \mathrm{ml} / \mathrm{min}$, and albuminuria $8 \pm 2 \mathrm{mg} / 24 \mathrm{~h}$.

The clinical characteristics of the diabetic patients are shown in Table 1. None of the diabetic patients received any drug other than insulin. Their metabolic control was satisfactory as demonstrated by the haemoglobin $A_{1 \mathrm{c}}$ levels, which were close to the upper limit of normal subjects. One week before the study, the patients were admitted to the ward to optimize insulin therapy by monitoring day by day glucose profiles.

The day before the study patients received only their usual subcutaneous short-acting insulin dose at 08.00 and 12.00 hours. They were then connected overnight to the Biostator (Miles, Ames, Cavenago, Italy) in order to clamp blood glucose at $4.7 \mathrm{mmol} / 1$ [11]. In all patients this value was achieved and maintained at least $10 \mathrm{~h}$ before the investigation. Overnight insulin infusion rate was on average $1.2 \pm 0.3 \mathrm{IU} / \mathrm{h}$ (Monocomponent crystalline porcine insulin NOVO, Actrapid MC, Novo Italiana, Rome). The studies were performed according to the principles of the declaration of Helsinki.

\section{Procedures and experimental design}

At 07.00 hours a wrist vein of normal subjects and diabetic patients was cannulated in retrograde manner and the hand placed in a warming box to arterialize hand venous blood [11]. Intermittent blood samples were drawn from this vein to measure hormone and metabolite blood levels.

Only diabetic patients received a constant intravenous insulin infusion $\left(15 \mathrm{mU} \cdot \mathrm{kg}^{-1} \cdot \mathrm{h}^{-1}\right)$ by an independent pump (Harvard Apparatus, Millis, Mass, USA). Both normal subjects and diabetic patients were connected to the Biostator in run mode $9: 1$ to perform a completely automated blood glucose clamp at $4.7 \mathrm{mmol} / 1$ [12]. Glomerular filtration rate (GFR) was measured by means of a constant $0.7 \mu \mathrm{Ci}$ infusion of ${ }^{51} \mathrm{Cr}$-EDTA (Specific activity: $1-2 \mu \mathrm{Ci} / \mathrm{mg} \mathrm{Cr}$, Amersham Ltd, Buckinghamshire, $\mathrm{UK}$ ) preceded by a priming dose of $50 \mu \mathrm{Ci}$ tracer $[4,13]$.

Renal plasma flow (RPF) was calculated by a constant infusion of $0.2 \mu \mathrm{Ci}{ }^{125} \mathrm{~T}$-hippurate [14] preceded by a priming dose of $30 \mu \mathrm{Ci}$ tracer.
At 07.00 hours the subjects drank one liter of tap water. To further obtain constant diuresis, 0.21 of water was given every $30 \mathrm{~min}$ throughout the study. At 08.00 hours ${ }^{51} \mathrm{Cr}$-EDTA and ${ }^{125} \mathrm{I}$-hippurate solutions were started.

To achieve a steady state condition with regard to urinary flow, ${ }^{51} \mathrm{Cr}$-EDTA and ${ }^{125}$ I-hippurate blood concentrations, measurements were commenced in the supine position after a period of $120 \mathrm{~min}$ at 10.00 hours. The subjects stood only to void. The above described procedure was followed in the following three protocols:

Study 1. Kidney function was investigated in seven Type 1 diabetic patients (patients 1 to 7 in Table 1) and in seven normal subjects receiving $2 \mathrm{~h}$ intravenous infusion of isotonic saline $\left(25 \mu \mathrm{mol} \cdot \mathrm{kg}^{-1}\right.$. $\left.\min ^{-1}\right)\left(0.730 \pm 0.101 \mathrm{l} \cdot \mathrm{h}^{-1}\right.$; molar concentration of the infused solution $0.154 \mathrm{~mol} / \mathrm{l})$, then $2 \mathrm{~h}$ acetoacetic acid infusion $(25 \mu \mathrm{mol}$. $\left.\mathrm{kg}^{-1} \cdot \mathrm{min}^{-1}\right)\left(0.730 \pm 0.1011 \cdot \mathrm{h}^{-1}\right.$; molar concentration of the infused solution $0.154 \mathrm{~mol} / 1$ ) and then again $2 \mathrm{~h}$ isotonic saline $\left(25 \mu \mathrm{mol} \cdot \mathrm{kg}^{-1} \cdot \mathrm{min}^{-1}\right)$. Four clearance periods were carried out during each infusion.

Study 2. Kidney function was studied in other seven diabetic patients (patients 8 to 14 in Table 1) and seven normal subjects with the same procedure described above, except that the rate of infusion either for saline or for acetoacetic acid was $15 \mu \mathrm{mol} \cdot \mathrm{kg}^{-1} \cdot \mathrm{min}^{-1}$ (fluid infusion rate $0.438 \pm 0.071 \mathrm{l} \cdot \mathrm{h}^{-1}$; molar concentration of the infused solution $0.154 \mathrm{~mol} / \mathrm{l}$ ).

Study 3. Kidney function was studied in five normal subjects and five diabetic patients (Numbers 9, 11, 13, 14, 15 in Table 1) with the same procedure described above except that hydrochloric acid, instead of acetoacetic acid, was infused at a rate of $10 \mu \mathrm{mol} \cdot \mathrm{kg}^{-1}$. $\min ^{-1}$ (fluid infusion rate $0.292 \pm 0.0691 \cdot \mathrm{h}^{-1}$; molar concentration infused solution $0.154 \mathrm{~mol} / \mathrm{l}$ ).

Sodium acetoacetate was prepared from ethyl acetoacetate (Riedel-De Haen Ag, Seelze-Hannover, FRG). Hydrolysis was performed with a $2 \mathrm{~N} \mathrm{NaOH}$ solution and incubation for $60 \mathrm{~min}$ at $45^{\circ} \mathrm{C}$. After neutralization with $1 \mathrm{~N} \mathrm{HCl}$, the solution was washed six times with diethylether and bubbled with $\mathrm{N}_{2}$ in crushed ice $[15,16]$.

Acetoacetic acid was produced by passing sodium acetoacetate solution through a $1.0 \mathrm{~m}$ glass column $(4 \mathrm{~cm}$ I.D.) containing a cation exchange resin (AG 50W-X8 100-200 mesh hydrogen form BioRad, Richmond, Calif, USA) at $2^{\circ} \mathrm{C}$ temperature. The $\mathrm{pH}$ of the 
acetoacetic acid solution after passing through this column was 1.9 , with a $1.4 \mathrm{~mol} / 1$ concentration versus a theoretical $1.69 \mathrm{~mol} / 1 \mathrm{con}-$ centration (recovery $78 \%$ ). Further procedures have been previously described [15]. The solution of hydrochloric acid had a $\mathrm{pH}$ of 0.99 . All the delivered solutions were nearly isotonic $(0.154 \mathrm{~mol} / 1)$. All the solutions of tracers, acetoacetic acid and hydrochloric acid were set up the day before each study and passed through a Millipore filter $(0.22 \mu \mathrm{m}$ Millipore Corp. Bedford, Mass, USA), kept frozen at $-20^{\circ} \mathrm{C}$ during the night and kept cool with ice cold water flowing through a polyethylene coil around the infusate syringes during the experiments. All the infusates were administered through a polyethylene coil around the infusate syringes during the experiments. All the infusates were administered through a polyethylene catheter manually advanced to the superior vena cava (Drum Cartridge, $\mathrm{Ab}$ bott Lab, Chicago, Ill, USA).

Albumin and $\beta_{2}$ microglobulin were measured by radioimmunoassay techniques $[17,18]$. The lowest detection limit for urine albumin assay was $1.5 \mu \mathrm{g} / \mathrm{ml}$. Normal range for albuminuria was $0.7-13.8 \mu \mathrm{g} / \mathrm{min}$. Total proteinuria was measured according to the technique of Bradford [19]. Normal range for proteinuria was $15-100 \mu \mathrm{g} / \mathrm{min}$.

Blood glucose was measured with an analyzer using the hexokinase method [20]. 3-hydroxybutyrate was measured using an automated fluorimetric technique as described by Lloyd et al. [21]. Acetoacetate was measured according to the spectrophotometric technique of Price et al. [22].

Free insulin was measured in plasma previously treated by polyethylene glycol both in normal subjects and diabetic patients by radioimmunoassay techniques [23]. Free insulin intra-assay and interassay coefficients of variation were $6 \%$ and $8 \%$ respectively. Glucagon and growth hormone plasma levels were measured by radioimmunoassay techniques $[24,25]$. Intra-assay and interassay coefficients of variation were $7 \%$ and $9 \%$, respectively, for glucagon and $5 \%$ and $7 \%$, respectively, for growth hormone. C-peptide was measured by radioimmunoassay technique [26] using the Biodata method (Biodata, Milan, Italy). The lowest limit of detection was $0.3 \mathrm{ng} /$ $\mathrm{ml}$. The intra-assay and interassay coefficients of variation were $4 \%$ and $6 \%$ respectively. Haemoglobin $\mathrm{A}_{1 c}$ levels were determined according to the technique of Schwartz et al. [27]. The range of normal values was $4.0-6.3 \%$. The ${ }^{51} \mathrm{Cr}$-EDTA and ${ }^{125} \mathrm{I}$-hippurate radioactivity of the infusate tracer solution, plasma and urine samples were measured in a $\gamma$-counter (Hewlett-Packard, Padua, Italy). Plasma renin activity was measured by radioimmunoassay technique [28]. Heart rate and auscultatory blood pressure (Korotkoff IV method) were measured in the middle of each $60-\mathrm{min}$ period during the study. Plasma concentrations of sodium, potassium, bicarbonate, total protein and haematocrit were measured by standard methods.

\section{Statistical analysis}

The results are expressed as means $\pm \mathrm{SD}$. Two way analysis of variance was used to assess statistical differences between normal subjects and diabetic patients and between baseline saline and acetoacetic acid infusion values. Newmann Keuls test was then used to assess statistical differences between individual points [29]. A $p$ value of 0.05 was considered statistically significant.

\section{Results}

\section{Renal haemodynamics during euglycaemic insulin-glucose clamp}

Study 1 (Figs. 1 and 2). Total plasma ketone body concentration rose to a maximum level of $1.853 \pm$ $0.180 \mathrm{mmol} / 1(p<0.01$ vs basal level) in control subjects and to $2.127 \pm 0.160 \mathrm{mmol} / 1(p<0.01$ vs basal level) in diabetic patients during acetoacetic acid infusion

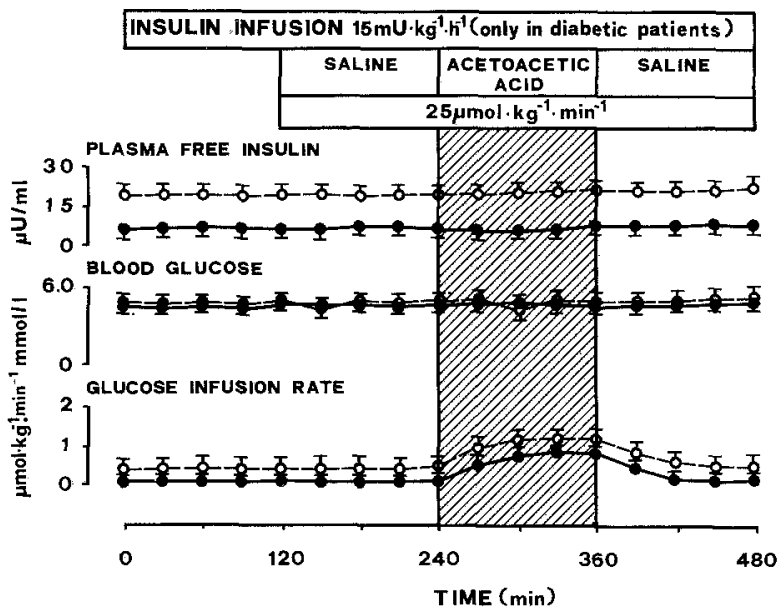

Fig. 1. Plasma free insulin, blood glucose and glucose infusion rate by Biostator device in seven control subjects $(\boldsymbol{\theta})$ and seven Type 1 diabetic patients $(O)$ during $25 \mu \mathrm{mol} \cdot \mathrm{kg}^{-1} \cdot \mathrm{min}^{-1}$ isotonic saline, $25 \mu \mathrm{mol}$ acetoacetic acid infusion and repeated isotonic saline infusion. Blood glucose was clamped at basal euglycaemic levels in both groups of subjects. Insulin was infused only in diabetic patients

$\left(25 \mu \mathrm{mol} \cdot \mathrm{kg}^{-1} \cdot \mathrm{min}^{-1}\right)$. Blood glucose and plasma free insulin concentrations were clamped at basal levels. Glucose requirements by the Biostator device increased during acetoacetic acid infusion from $0.08 \pm$ $0.03 \mu \mathrm{mol} \cdot \mathrm{kg}^{-1} \cdot \mathrm{min}^{-1}$ during isotonic saline infusion to $0.95 \pm 0.27(p<0.01)$ in normal subjects and from $0.49 \pm 0.23$ to $1.15 \pm 0.21(p<0.01)$ in diabetic patients (Fig. 1).

Plasma glucagon concentrations during acetoacetic acid administration $(52 \pm 8$ and $74 \pm 11 \mathrm{pg} / \mathrm{ml}$ in normal subjects and diabetic patients respectively) were comparable to the hormonal patterns observed during saline infusion $(50 \pm 14$ and $77 \pm 16 \mathrm{pg} / \mathrm{ml}$ in normal subjects and diabetic patients). Basal growth hormone levels of diabetic patients $(5 \pm 3 \mathrm{ng} / \mathrm{ml})$ and of normal subjects $(6 \pm 2 \mathrm{ng} / \mathrm{ml})$ were unchanged during acetoacetic acid infusion $(6 \pm 4 \mathrm{ng} / \mathrm{ml}$ in diabetic patients and $7 \pm 2$ in normal men). Plasma renin activity was comparable in normal subjects and diabetic patients during saline infusion $\left(1.03 \pm 0.40 \mathrm{ng} \cdot \mathrm{ml}^{-1} \cdot \mathrm{h}^{-1}\right.$ in control subjects vs $0.92 \pm 0.37$ in diabetic patients) and decreased significantly at the end of acetoacetic acid infusion in both groups $(0.64 \pm 0.30$ in control subjects vs $0.60 \pm 0.22$ in diabetic patients $(p<0.01)$ ). GFR increased from a basal value of $117 \pm 8$ to $145 \pm 7 \mathrm{ml}$. $\min ^{-1} \cdot 1.73 \mathrm{~m}^{-2}(p<0.01)$ during acetoacetic acid infusion (24\% increase) in control subjects and from $135 \pm 9$ to $180 \pm 8(p<0.001)(33 \%$ increase $)$ in diabetic patients (Fig. 2). RPF was $590 \pm 71$ and $657 \pm 88 \mathrm{ml}$. $\min ^{-1} \cdot 1.73 \mathrm{~m}^{-2}$ in normal subjects and diabetic patients, respectively, during saline infusion, and was significantly increased to $691 \pm 135(p<0.05)$ and $762 \pm$ $81(p<0.005)$ by acetoacetic acid infusion in normal subjects and diabetic patients respectively (Fig. 2).

When acetoacetic acid infusion was stopped and again replaced by saline infusion $\left(25 \mu \mathrm{mol} \cdot \mathrm{kg}^{-1}\right.$. 


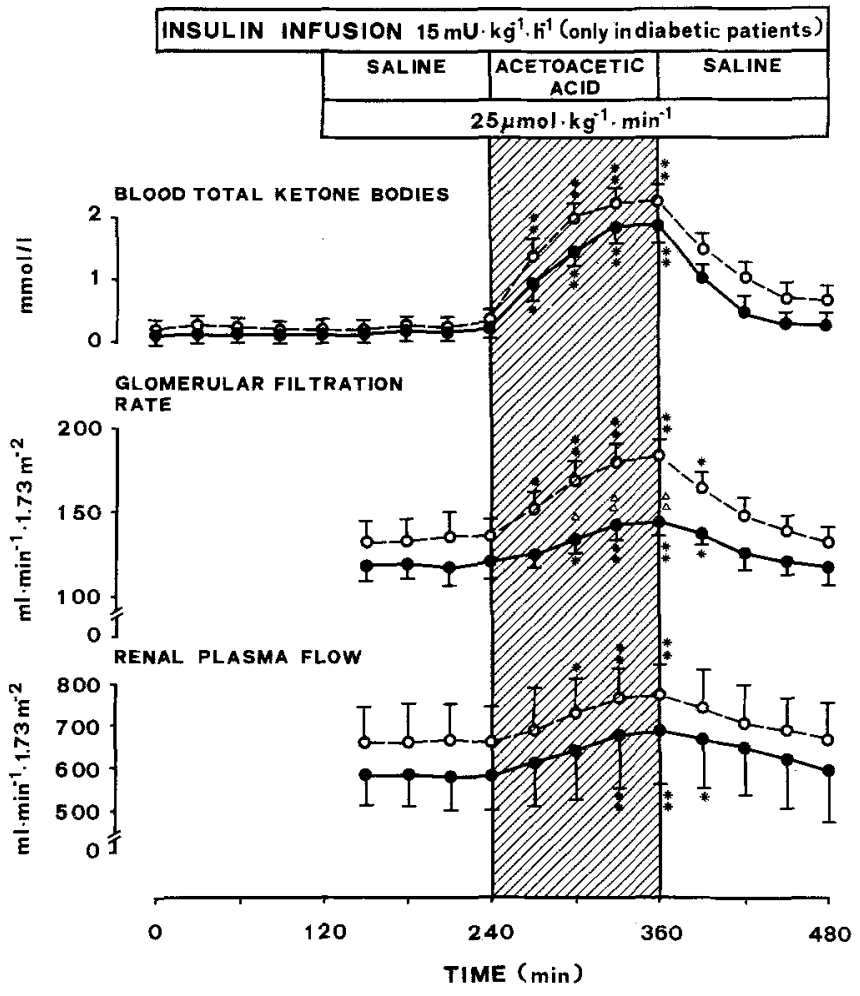

Fig. 2. Blood total ketone bodies (acetoacetate plus 3-hydroxybutyrate) glomerular filtration rate and renal plasma flow in the seven control subjects $(\bullet)$ and seven Type 1 diabetic patients $(O)$ during $25 \mu \mathrm{mol} \cdot \mathrm{kg}^{-1} \cdot \mathrm{min}^{-1}$ repeated isotonic saline infusion. ${ }^{*} p<0.05$, ${ }^{* *} p<0.01$ baseline saline vs acetoacetic acid infusion values; $\Delta p<$ $0.05, \Delta \Delta p<0.01$ control subjects vs diabetic patients

$\min ^{-1}$ ), glucose requirement, total ketone body concentration, GFR and RPF decreased to the values observed during basal saline infusion. Urinary flow as well as blood pressure were not modified by ketone administration. The filtration fraction was $0.20 \pm 0.04$ and $0.21 \pm 0.06$, respectively, in normal subjects and diabetic patients during saline infusion. Acetoacetic acid infusion increased the filtration fraction significantly $(p<0.05)$ in comparison with baseline saline infusion in diabetic patients $(0.24 \pm 0.04, p<0.05)$ but not in control subjects $(0.21 \pm 0.06)$. When acetoacetic acid was replaced again by saline infusion, both GFR and RPF decreased in control subjects and diabetic patients to the values found during baseline saline infusion (Fig. 2).

Ketone body tubular reabsorption rate was $11.7 \pm$ 2.3 and $22.8 \pm 4.3 \mu \mathrm{mol} \cdot \mathrm{min}^{-1} \cdot 1.73 \mathrm{~m}^{-2}$ in control subjects and in diabetic patients, respectively, during saline infusion and $214.9 \pm 19.3$ and $306.3 \pm 33.7$, respectively, during acetoacetic acid infusion.

Plasma sodium concentrations $(142.7 \pm 3.5 \mathrm{mmol} / 1$ in control subjects vs $143.4 \pm 3.3$ in diabetic patients) were comparable between both study groups and did not differ both during acetoacetic acid infusion $(142.8 \pm 3.2$ in control subjects vs $143.3 \pm 2.3$ in diabetic patients) and during saline infusion of the recovery

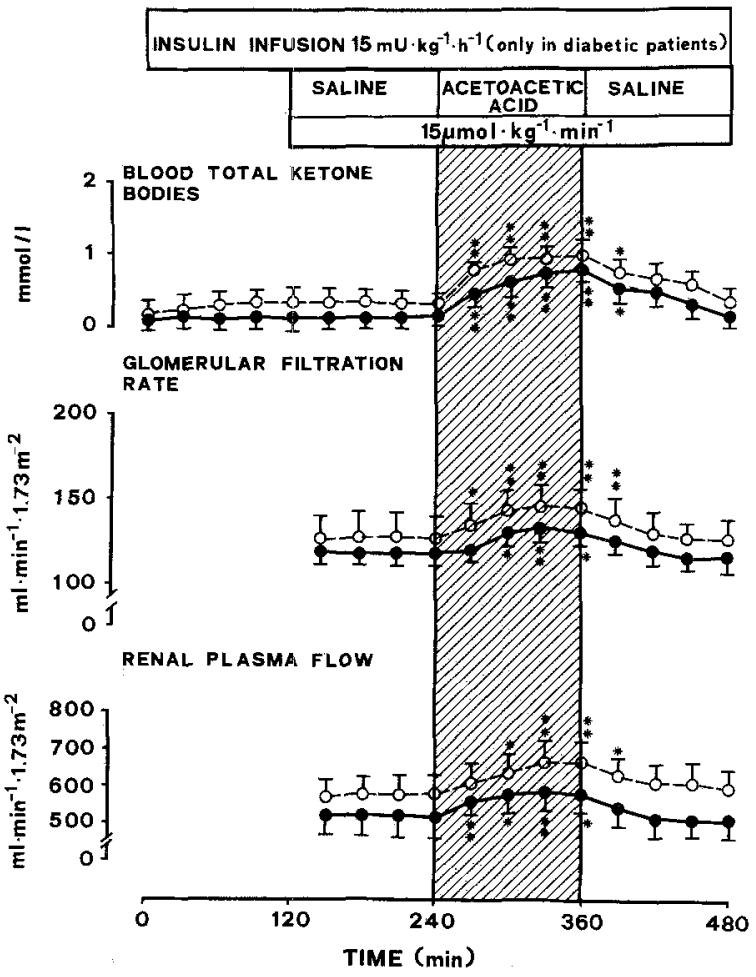

Fig. 3. Blood total ketone body concentrations, glomerular filtration rate and renal plasma flow in seven control subjects $(\boldsymbol{O})$ and seven Type 1 diabetic patients $(O)$ during $\left(15 \mu \mathrm{mol} \cdot \mathrm{kg}^{-1} \cdot \mathrm{min}^{-1}\right)$ isotonic saline and $\left(15 \mu \mathrm{mol} \cdot \mathrm{kg}^{-1} \cdot \mathrm{min}^{-1}\right)$ acetoacetic acid infusion. Other details as in Figure 1

phase $(141.9 \pm 3.4$ in control subjects vs $142.9 \pm 2.7$ in diabetic patients).

Basal $\mathrm{pH}$ and bicarbonate plasma concentrations were $7.382 \pm 0.021$ and $26.1 \pm 1.4 \mathrm{mmol} / 1$ in normal subjects and $7.392 \pm 0.032$ and $25.6 \pm 2.2 \mathrm{mmol} / 1$ in diabetic patients, respectively, during isotonic saline infusion. During acetoacetic acid infusion, $\mathrm{pH}$ and bicarbonate plasma concentrations did not change significantly in both groups (7.384 \pm 0.04 and $25.0 \pm$ $1.7 \mathrm{mmol} / 1$ in control subjects and $7.389 \pm 0.031$ and $23.0 \pm 1.3 \mathrm{mmol} / 1$ in diabetic patients). During the recovery phase saline infusion the $\mathrm{pH}$ and bicarbonate plasma concentrations were $7.389 \pm 0.039$ and $24.9 \pm$ $1.9 \mathrm{mmol} / 1$ in control subjects and $7.393 \pm 0.042$ and $24.2 \pm 1.7 \mathrm{mmol} / 1$ in diabetic patients.

The haematocrit decreased equally in both groups. During the first saline infusion the haematocrit was $45 \pm 2 \%$, during acetoacetic acid infusion $43 \pm 1 \%$, and during the second saline infusion $43 \pm 2 \%$ in control subjects; in diabetic patients during the first saline infusion the haematocrit was $44 \pm 3 \%$, during acetoacetic acid infusion $42 \pm 2 \%$, and during second saline infusion $41 \pm 3 \%$. During the first saline, acetoacetic acid and second saline infusion plasma protein concentrations were $7.0 \pm 0.1 \mathrm{~g} / \mathrm{dl}, 6.8 \pm 0.3$ and $6.8 \pm 0.4$ in control subjects and $6.9 \pm 0.7,6.7 \pm 0.8$ and $6.6 \pm 0.9$ in diabetic patients. 


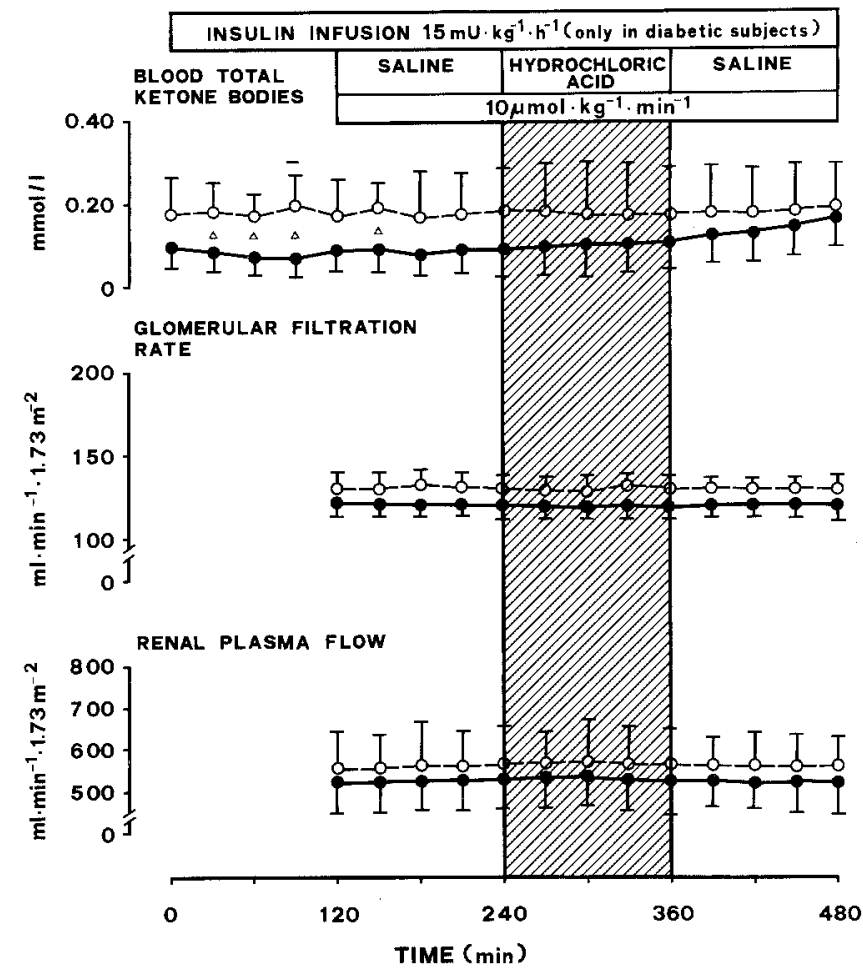

Fig.4. Blood total ketone bodies, glomerular filtration rate and renal plasma flow in five control subjects (O) and in five Type 1 diabetic patients (O) during $\left(10 \mu \mathrm{mol} \cdot \mathrm{kg}^{-1} \cdot \mathrm{min}^{-1}\right)$ saline and $\left(10 \mu \mathrm{mol} \cdot \mathrm{kg}^{-1} \cdot \mathrm{min}^{-1}\right)$ hydrochloric acid infusion. Other details as in Figure 1

Arterial blood pressure did not change significantly during the study $(123 / 80 \pm 6 / 6 \mathrm{mmHg}$ during isotonic saline infusion and $121 / 81 \pm 7 / 8 \mathrm{mmHg}$ during acetoacetic acid infusion in diabetic patients; $120 / 80 \pm$ $5 / 4 \mathrm{mmHg}$ in normal subjects before and $121 / 78 \pm$ $7 / 7 \mathrm{mmHg}$ during acetoacetic acid infusion). No variation was observed in heart rate in the two groups during the experiment.

Study 2 (Fig. 3). $15 \mu \mathrm{mol} \cdot \mathrm{kg}^{-1} \cdot \mathrm{min}^{-1}$ acetoacetic acid infusion resulted in an increase in circulating levels of total ketone bodies which increased to a peak concentration of $0.761 \pm 0.182 \mathrm{mmol} / 1$ and $0.993 \pm 0.092$ $\mathrm{mmol} / 1$ in normal subjects and diabetic patients respectively. GFR increased from a basal value of $119 \pm$ 6 to $130 \pm 6 \mathrm{ml} \cdot \mathrm{min}^{-1} \cdot 1.73 \mathrm{~m}^{-2}(p<0.01)$ during acetoacetic acid infusion ( $9 \%$ increase) in control subjects and from $126 \pm 11$ to $146 \pm 10(p<0.01)(16 \%$ increase $)$ in diabetic patients. RPF was $531 \pm 67$ and $579 \pm$ $62 \mathrm{ml} \cdot \min ^{-1} \cdot 1.73 \mathrm{~m}^{-2}$ in control subjects and diabetic patients, respectively, during saline infusion and in control subjects $(p<0.05) \quad 599 \pm 52 \mathrm{ml} \cdot \mathrm{min}^{-1}$. $1.73 \mathrm{~m}^{-2}$ and $667 \pm 88 \mathrm{ml} \cdot \mathrm{min}^{-1} \cdot 1.73 \mathrm{~m}^{-2}$ in diabetic patients $(p<0.05)$, respectively, during acetoacetic acid infusion. The filtration fraction was $0.22 \pm 0.08$ and $0.22 \pm 0.07$ in control subjects and diabetic patients during saline infusion and $0.22 \pm 0.07$ and $0.22 \pm 0.08$
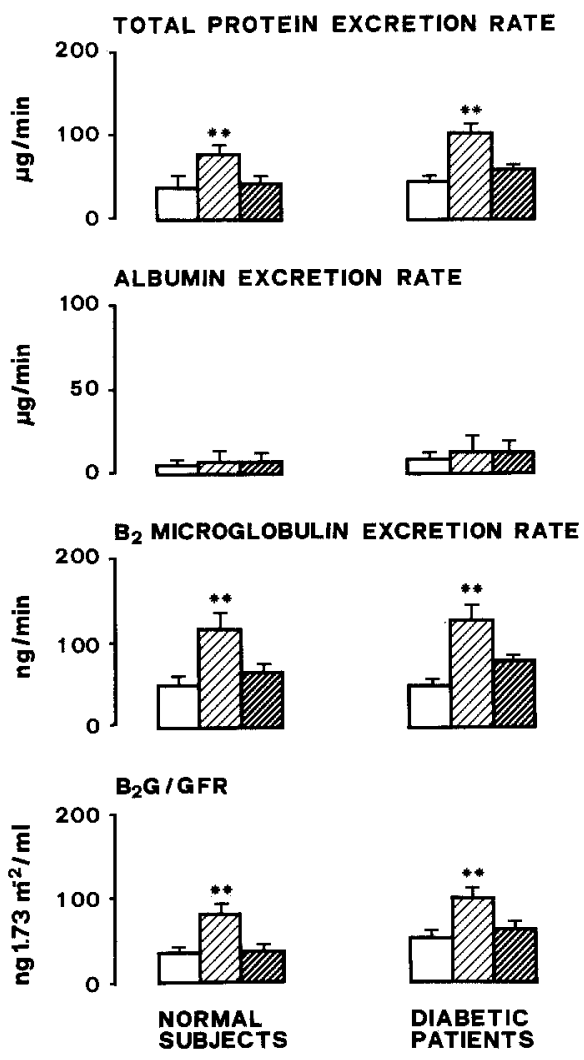

Fig.5. Total protein, albumin, $\beta 2$-microglobulin urinary excretion rate in control subjects and Type 1 diabetic patients. 1, 2 and 3 columns indicate the mean value during infusion of isotonic saline, acetoacetic acid $\left(25 \mu \mathrm{mol} \cdot \mathrm{kg}^{-1} \cdot \mathrm{min}^{-1}\right)$ and repeated isotonic saline. $\beta 2-\mathrm{G} / \mathrm{GFR}$ indicates the ratio between the urinary excretion rate of $\beta 2$-microglobulin and glomerular filtration rate. ${ }^{* *} p<0.01$ baseline saline vs acetoacetic acid infusion values

in control subjects and diabetic patients during acetoacetic acid infusion.

No change in $\mathrm{pH}$, plasma bicarbonate, arterial blood pressure or heart rate was seen during the study. The decrease in haematocrit and in plasma protein concentration was almost identical to that observed in Study 1.

Study 3 (Fig. 4). $10 \mu \mathrm{mol} \cdot \mathrm{kg}^{-1} \cdot \mathrm{min}^{-1}$ hydrochloric acid infusion did not cause any significant change in circulating levels of ketone bodies. Baseline GFR values were $121 \pm 8$ and $128 \pm 12 \mathrm{ml} \cdot \mathrm{min}^{-1} \cdot 1.73 \mathrm{~m}^{-2}$ in normal subjects and diabetic patients, respectively, and were not significantly changed by hydrochloric acid infusion (119 \pm 9 and $127 \pm 13)$. RPF was $527 \pm 77$ and $564 \pm 72 \mathrm{ml} \cdot \mathrm{min}^{-1} \cdot 1.73 \mathrm{~m}^{-2}$ in normal subjects and diabetic patients, respectively, during baseline saline infusion and did not change during hydrochloric acid administration (531 \pm 84 and $651 \pm 93$ respectively). Basal $\mathrm{pH}$ and plasma bicarbonate concentrations were $7.385 \pm 0.022$ and $25.7 \pm 1.5 \mathrm{mmol} / 1$ in normal subjects and $7.391 \pm 0.031$ and $25.2 \pm 1.6 \mathrm{mmol} / 1$ in diabetic patients during baseline saline infusion. Hydrochloric acid infusion resulted in a significant decrease in $\mathrm{pH}$ 
values both in normal subjects and diabetic patients $(7.361 \pm 0.019, p<0.01$ and $7.372 \pm 0.021, p<0.01$ respectively). Plasma bicarbonate concentration also decreased significantly to a value of $24.3 \pm 1.3 \mathrm{mmol} / 1$ in normal subjects $(p<0.05)$ and a value of $23.9 \pm 1.7$ in diabetic patients $(p<0.01)$. No changes in arterial blood pressure, heart rate and plasma concentrations of glucagon and growth hormone were observed during hydrochloric acid infusion in comparison with baseline saline infusion. The decrease in haematocrit and in plasma protein concentration was similar to that shown during Study 2.

\section{Urinary protein excretion rates}

Figure 5 shows total protein, albumin and $\beta 2$-microglobulin urinary excretion rate determined in Study 1 of normal subjects and diabetic patients during isotonic saline, acetoacetic acid and isotonic saline infusions. Acetoacetic acid administration significantly $(p<0.01)$ increased total protein and $\beta 2$-microglobulin excretion rate without affecting albumin excretion rate both in normal subjects and diabetic patients. The ratio between $\beta 2$-microglobulin excretion rate and GFR was also significantly elevated $(p<0.05)$ by acetoacetic administration in both groups of subjects. The patterns of $\beta 2$-microglobulin excretion rate during the final isotonic saline infusion decreased to the levels found during baseline saline administration.

\section{Discussion}

An elevated GFR in patients with early short-term Type 1 diabetes mellitus has been found by several authors [1-5]. There is evidence suggesting that an increased blood flow resulting in an increased GFR can contribute to the development of diabetic glomerulosclerosis $[7,30]$.

The purpose of the present study was to investigate whether an acute increase in blood levels of ketone bodies at stable plasma levels of glucose and insulin was capable of increasing GFR both in normal subjects and diabetic patients. Two rates of acetoacetic acid infusion were chosen in order to achieve circulating concentrations of ketone bodies in the range usually observed in poorly controlled diabetic patients during subcutaneous insulin therapy or in a more advanced ketotic state even without acidosis or dehydration [31].

In both groups of subjects blood glucose was clamped at $4.7 \mathrm{mmol} / 1$ throughout the entire experiment. Glucagon and growth hormone concentrations were not modified by acetoacetic acid administration. GFR was significantly enhanced by acetoacetic acid administration both at low and high infusion rates. This effect was dose-dependent, since the increase in GFR was twice as great at high than at low acetoacetic acid infusion. Diabetic patients showed a greater in- crease in GFR following ketone body challenge than normal subjects. The increase in GFR was associated in both groups with an enhancement in RPF.

The saline period and the acetoacetic acid infusion period did not differ with regard to volume and tonicity of administered infusates.

In order to rule out that the haemodynamic effects induced by acetoacetic acid were due to the amount of acid given (i.e. the protons associated to the acetoacetate), we infused hydrochloric acid both in normal subjects and diabetic patients. Hydrochloric acid administration had no effect on GFR and RPF, even if there was a significant decrease in blood $\mathrm{pH}$.

As for the amount of sodium administered, we have previously shown an increase in GFR values similar to that found in the current study, during the administration of the sodium salt of ketone bodies [32], suggesting that the haemodynamic changes are due to the acid form of the organic acid rather than to changes in the amount of administered sodium. Moreover, the increase in GFR and RPF cannot be due to sodium and water loading throughout the study, since GFR and RPF returned to basal levels as soon as acetoacetic acid infusion was stopped and saline was again infused. These results are in agreement with previous reports which demonstrated that GFR and RPF remained unchanged during sustained water diuresis $[33,34]$ and during infusion of more than $50 \mathrm{ml} / \mathrm{min}$ of isotonic saline [35]. With regard to plasma renin activity (PRA), we did not find any increase in circulating pattern of PRA during acetoacetic acid administration, suggesting that renin-angiotensin II system is not activated by ketone body administration. Thus, a specific effect of ketone bodies has to be postulated to account for the findings of the present study. It has been reported that RPF is elevated in short-term diabetic patients and a positive correlation between RPF and GFR has been demonstrated [37]. The current findings demonstrate that increase in blood levels of ketone bodies plays an independent role in the enhancement of RPF and GFR in Type 1 diabetes and suggest that the increase in GFR is at least partially due to an increase in RPF. Concerning this topic, blood flow is almost twice that of normal control subjects in the forearm of newly diagnosed poorly controlled diabetic patients [38]. Increased blood flow has also been reported in the brain, muscle, fat, skin and kidney in hyperglycaemic ketotic diabetic patients [38], and it can be completely normalized by strict metabolic correction [38]. We postulate that the increase in ketone body blood concentrations is the cause of a reversible vasodilatation resulting in an increased RPF at kidney site. With regard to the ketone body infusion at high rate, it has to be pointed out that the increase in RPF was similar in normal subjects and diabetic patients, whereas the elevation in GRF was higher in diabetic patients. This phenomenon was not evident at low ketone body infusion rates. Thus, filtration fraction was significantly increased by 
$25 \mu \mathrm{mol} \cdot \mathrm{kg}^{-1} \cdot \mathrm{min}^{-1}$ acetoacetic acid infusion in diabetic patients but not in normal subjects. With regard to this last finding it has been reported that Type 1 diabetic patients in poor metabolic control with elevated ketone body levels are characterized by a high filtration fraction which decreases towards normal value after one week of good metabolic control [37].

Ditzel et al. [39] found that an increased plasma (and ultrafiltrate) glucose concentration leads to a stimulation of sodium-coupled glucose reabsorption and thereby of solute-linked water reabsorption.

The excess sodium-solute-linked reabsorption was interpreted to be basic for the mechanism leading to the elevated GFR in the diabetic patients [39]. The role of ketone bodies from this point of view should be even more crucial, since reabsorptive rates of acetoacetate, 3-hydroxybutyrate and acetone increase linearly with their filtered loads, no maximal renal tubular transport rates were demonstrated for any ketone body [40] and renal reabsorption of ketone bodies is usually thought to be more efficient than that of glucose [40]. This unlimited capacity of the renal tubulus to transport ketone bodies coupled with sodium and ammonium could lead to a linearly related solute-linked water reabsorption.

In the current study we showed an acute effect of the marked increase of circulating ketone bodies on kidney haemodynamics. Further studies will be needed to investigate whether a similar effect is still present after a chronic increase in ketone bodies in blood. With regard to protein excretion rate following ketone body administration, we found that acetoacetic acid infusion significantly increased total protein and $\beta 2$-microglobulin but not albumin excretion rate. This effect was clearly observed both in normal subjects and in diabetic patients. These findings suggest that an acute shortterm increase in blood levels of ketone bodies enhances tubular but not glomerular proteinuria. Moreover, this finding is confirmed by the ratio between $\beta 2$-microglobulin excretion rate and GFR. Our results are in keeping with the recent report of Nagulesparan et al. [41], who observed a marked increase in total protein but not in albumin excretion rate in obese Type 2 (non-insulin-dependent) diabetic patients with high ketone body blood levels during prolonged fasting.

In conclusion, our results indicate that an acute short term increase in blood concentration of ketone bodies within a range often observed in diabetic patients in poor metabolic control although not in ketoacidosis (1) increases renal plasma flow and glomerular filtration rate in normal Type 1 diabetic patients; and (2) causes a tubular proteinuria, as suggested by higher excretion rate of total urinary protein and $\beta 2$-microglobulin without changes in albumin excretion rate.

These findings seem to be due to the effects of the organic acid itself rather than to the associated protons administered, since hydrochloric acid administration did not change renal haemodynamics.

Acknowledgements. This work was supported by Centro Nazionale delle Ricerche Grants nos. 840084904 and 840176604.

\section{References}

1. StalderG, Schmid R (1959) Severe functional disorders of glomerular capillaries and renal haemodynamics in treated diabetes mellitus during childhood, Ann Paediat 193: 129-138

2. Ditzel J, Schwartz M (1967) Abnormally increased glomerular filtration rate in short-term insulin-treated diabetic subjects. Diabetes 16: 264-267

3. Christiansen JS, Gammelgaard J, Frandsen M, Parving H-H (1981) Increased kidney size, glomerular filtration rate and renal plasma flow in short-term insulin-dependent diabetics. Diabetologia 20: 451-456

4. Mogensen CE (1971) Glomerular filtration rate and renal plasma flow in short-term and long-term juvenile diabetes mellitus. Scand J Clin Lab Invest 28: 91-100

5. VibertiGC, Keen H (1984) Patterns of proteinuria in diabetes mellitus. Diabetes 133: 686-691

6. WisemanJ, Saunders AJ, Keen H, VibertiGC (1985) Effect of blood control on increased glomerular filtration rate and kidney size in insulin-dependent diabetes. N Engl J Med 312: 617-621

7. Hostetter TH, RennkeHG, BrennerBM (1982) The case for intrarenal hypertension in the initiation and progression of diabetic and other glomerulopathies. Am J Med 72: 375-380

8. Christiansen IS (1984) On the pathogenesis of the increased glomerular filtration rate in short-term insulin-dependent diabetes. (Thesis) Laegeforeningens forlag, pp 1-44

9. Parving H-H, Christiansen JS, Noer I (1980) The effect of glucagon infusion on kidney function in short-term insulin-dependent juvenile diabetics. Diabetologia 20: 350-354

10. Christiansen JS, Gammelgaard J, Frandsen M (1982) Kidney function and size in type 1 (insulin-dependent) diabetic patients before and during growth hormone administration for one week. Diabetologia 22: 333-337

11. Nosadini R, Del Prato S, Tiengo A, DunerE, Toffolo G, CobelliC, Faronato P, MoghettiP, Muggeo M (1982) Insulin sensitivity, binding and kinetics in pancreatogenic and type I diabetes. Diabetes $31: 346-355$

12. Clements AH, Hough DL, D'Orazio PA (1982) Development of the biostator glucose clamping algorithm. Clin Chem 28: 1899-1908

13. Chantler C, GarnetES, Parsons V, Veale N (1969) Glomerular filtration rate measurement in man by the single injection method using ${ }^{51} \mathrm{Cr}$-EDTA. Clin Sci 37: 169-180

14. Ram MD, Evans K, Chisholm GD (1967) Measurements of effective renal plasma-flow by the clearance of ${ }^{125} \mathrm{I}$ hippuran. Lancet 1: 645-646

15. Nosadini R, Avogaro A, Trevisan R, Duner E, Marescotti C, Iori E, CobelliC, Toffolo G (1985) Acetoacetate and 3-hydroxybutyrate kinetics in obese and insulin-dependent diabetic humans. Am J Physiol 248: R611-R620

16. Fery F, Balasse EO (1980) Differential effects of sodium acetoacetate and acetoacetic acid infusions on alanine and glutamine metabolism in man. J Clin Invest 66: 323-331

17. Keen H, Chlouverakis C (1963) An immunoassay method for urinary albumin at low concentrations. Lancet 2: 913-914

18. Evrin PE, Peterson PA, Wide L, Berggard I (1971) Radioimmunoassay for $\beta 2$-microglobulin in human biological fluids. Scand $\mathrm{J}$ Clin Lab Invest 28: 439-443

19. Bradford MM (1976) A rapid and sensitive method for the quantitation of microgram quantities of protein utilizing the principle of protein-dye binding. Anal Biochem 72: 248-254

20. Huggett ASG, Nixon DA (1957) Use of glucose-oxidase, peroxi- 
dase and $\mathrm{O}$-dianisidine in determination of blood and urinary glucose. Lancet 2: $368-370$

21. Lloyd B, Burrin J, Smithe P, Alberti K (1978) Simple automated enzymatic fluorimetric assay for blood glucose, lactate, pyruvate, alanine, glycerol and 3-hydroxybutyrate. Clin Chem 24: 1724-1729

22. Price C, Lloyd B, Alberti K (1977) A kinetic spectrophotometric assay for rapid determination of acetoacetate in blood. Clin Chem 23: 1893-1897

23. NagakawaS, Hakayama H, Sasaky T, Yoshino K, Yu YY, Shinozaki K, AokiS, Mashino K (1973) A simple method for the determination of serum free insulin levels in insulin-treated patients. Diabetes 22: 590-600

24. Faloona G, Unger RH (1974) Glucagon. In: Jaffe B, Behrman $H$ (eds) Methods of hormone radioimmunoassay. Academic Press, New York, pp 317-330

25. Peake GT (1974) Growth hormone. In: Jaffe B, Behrman H (eds) Methods of hormone radioimmunoassay. Academic Press, New York, pp 103-121

26. Heding L (1975) Radioimmunological determination of human $C$ peptide in serum. Diabetologia 11: $541-548$

27. SchwartzHC, King C, SchwartzAL, Edmunds D, Schwartz R (1976) Effects of pregnancy on hemoglobin $A_{1 c}$ in normal gestional diabetic women. Diabetes $25: 1118-1128$

28. SealeyJE, Gerten-Banes J, Laragh W (1972) The renin system: variations in man measured by radioimmunoassay or bioassay. Kidney Int 1: 240-253

29. SnedecorGW, Cochran WG (1967) Statistical methods. Iowa State University Press, Ames, Iowa

30. Mauer SM, Steffes MW, AzarS, Sandberg SK, Brown DM (1978) The effect of Goldblatt hypertension on the development of glomerular lesions of diabetes mellitus in the rat. Diabetes 27: 738-744

31. Nosadini R, Noy G, Nattrass M, Hadson A, Johnston D, Burrin J, OrskovH, Alberti KGMM (1982) The metabolic and hormonal response to acute normoglycaemia in type 1 (insulin-dependent) diabetes. Diabetologia 23: 220-228

32. Trevisan R, Nosadini R, Fioretto P, Iori E, AvogaroA, DunerE (1986) The effects of ketone body infusion on kidney function in normal and insulin-dependent diabetic subjects. Eur J Clin Invest 16: 48 (Abstract)

33. Chapman CB, Henschel A (1949) The effect of water diuresis on renal plasma flow. Science 109: 232-233

34. Brochner-Mortensen J (1973) The glomerular filtration rate during moderate hyperglycaemia in normal man. Acta Med Scand 194: 31-37

35. Crawford B, Ludemann $H$ (1951) The renal response to intravenous injection of sodium chloride solutions in man. J Clin Invest 30: 1456-1462

36. DuBois D, DuBois F (1916) A formula to estimate the approximate surface area if height and weight be known. Arch Intern Med 17: 863-871

37. Mogensen CE (1972) Kidney function and glomerular permeability to macromolecules in early juvenile diabetes. (Thesis) Dan Med Bull [Suppl 3] 19: 1-40

38. Parving $\mathrm{H}-\mathrm{H}$, Viberti GC, Keen H, Christiansen JS, Lassen NA (1983) The haemodynamic origin of diabetic microangiopathy. Metabolism 32: 943-949

39. Ditzel J, Brochner-Mortesen J (1983) Tubular reabsorption rates as related to elevated glomerular filtration in diabetic children. Diabetes 32 [Suppi 2]: 28-33

40. Owen OE, LichtJH, Sapir DG (1981) Renal function and effects of partial rehydration during diabetic ketoacidosis. Diabetes 30 : $510-518$

41. Nagulesparan M, FlockEV, KennedyA, Baird R, BennetPH (1985) Increased proteinuria during fasting in obese non-insulindependent diabetics. Diabetic Nephrop 1: 150-155

Received: 26 May 1986

and in revised form: 17 February 1987

Dr. R. Nosadini

Patologia Medica I

Istituto di Medicina Interna

Policlinico Universitario

I-35100 Padova

Italy 